\title{
STRENGTHENING OF INTERIOR SLAB COLUMN CONNECTIONS VIA POST INSTALLED STEEL SHEAR BOLTS
}

\author{
H. El-Esnawi \\ Civil Engineering Dept., Faculty of Engineering, Al-Azhar University, Egypt
}

\begin{abstract}
Flat slabs are widely used in construction operations because of their simplicity and ease. However, this type of structures can be subjected to brittle punching shear failure in the slabcolumn connections. Without shear reinforcement, the slab column connection can suffer brittle punching failure. In order to overcome the risk of brittle punching shear failure in the column vicinity, the use of post installed shear bolts as a transverse reinforcement is investigated in this paper. A set of six half scale reinforced concrete slab column connections were tested under monotonic concentric load. Three of the tested specimens were provided with steel shear bolts after the hardening of the concrete. Results indicated an enhanced punching strength for specimens provided with steel shear bolts. The increase in punching capacity was combined with a significant increase in both ductility and rotational capacity.
\end{abstract}

\section{KEYWORDS : Slab-column connections; punching shear; ductility; experimental; strengthening.}

\section{INTRODUCTION}

Flat slabs are subjected to the risk of brittle punching failure at the slab column connection. Figure (1) shows an elevation view of an interior slab column connection transferring shear force V caused by gravity loads. Flexural cracks appear on top of the slab. In addition, a diagonal shear crack develops within the slab thickness. Once shear strength of the slab column connection is reached, the diagonal shear cracks cross the full slab thickness forming a trenched cone or pyramid. This punching failure is risky since it occurs suddenly in a brittle manner. Modern building codes require a building to be designed in a way that a local failure shall not lead to a progressive collapse of the entire structure, but flat plates does not fulfill this basic requirement because it has a very limited rotational capacity at the columns. Punching will occur when the rotational capacity is exceeded. A punching failure may probably lead to subsequent punching at the adjacent columns due to large slab rotations, and the risk of a progressive collapse is imminent. In order to overcome the major disadvantage of flat slabs, previous researchers investigated the efficiency of several strengthening techniques. The use of shear studs in the column vicinity is one of the famous strengthening techniques. Figure (2) shows shear stud reinforcement in a slab column connection. Another method for ductility enhancement is the use of bent bars and stirrups in the column vicinity as shown in figure (3). Broms provided a detailing for ductility using a combination of bent bars and stirrups. Strengthening of slab column connections can be done also after slab construction. Strengthening is needed due to a design or/and construction mistake, or due to changing the function of the building. Fiber reinforced polymers can be used as a transverse reinforcement in slab column connections. Increasing the flexural reinforcement ratio has a significant effect on increasing the punching shear capacity of slab-column connections. It also increases the post-cracking stiffness and decreases the ductility of the connections Rizk et al. 2011 
In this paper a technique of installing steel shear bolts for strengthening the punching shear zone in pre-casted concrete slab specimens in orthogonal direction. These bolts extend to a distance covering the shear punching zone. They were tightened with a constant torque to ensure fare comparative results analysis.

\section{EXPERIMENTAL PROGRAM}

\subsection{Specimens preparation}

A total of six isolated slab-column connections with different tensile reinforcement ratios were tested under concentric punching load up to failure. Test specimens are divided into two groups, each of three specimens having tensile reinforcement ratios $\rho \%$ of $0.58,0.78$ and 1.4. First group is un-strengthened and labeled NS1, NS2 and NS3, while second group is strengthened and labeled SS1, SS2 and SS3. These specimens can be regarded as a part of a prototype roof. The isolated test specimens investigated in this experimental program represent a half scale interior slab column connection bounded by the moment contra-flexure lines around the column, as shown in figure (4). The slab dimensions of all tested specimens were $(1800 \times 1800 \times 100 \mathrm{~mm}$.$) , and, the column dimensions of all tested specimens was$ (150x150x350mm.). Table (1) summarizes the dimensions and reinforcement details of the specimens. Concrete compressive strength $f_{c}$ for all specimens was found by testing three standard cylinders for each specimen. Concrete mix was designed to produce concrete compressive strength equals to $35 \mathrm{MPa}$. Due to the variation of concrete production and period of curing, different $f_{c}$ values were obtained. Relationships held in this paper-adopted a normalization of the effect of the $f_{c}$ variation by dividing shear stress values by ${ }^{c}$.

\subsection{Installation of the steel shear bolts}

The strengthened test specimens was provided with high strength steel shear bolts of a diameter $12 \mathrm{~mm}$, the grade of shear bolts was 8.8. They were installed in the concrete slab of the specimens after drilling $12.5 \mathrm{~mm}$ diameter holes through the slab. Figure (5) shows a slab specimen with drilled holes. However, after completing the drilling process, steel shear bolts were installed in the concrete slab through the drilled holes. The bolts were then tightened against the slab by a standard torque wrench. The tightening torque was kept constant for all specimens with a value of $(70$ N.M). Figure (6) shows a strengthened slab after the installation process of shear bolts.

\subsection{Test setup and Instrumentation}

The layout and dimensions of the testing frame is shown in figure (8). Data acquisition system has been used to monitor and record the load magnitude and the strains in the flexural reinforcement, as well as concrete strain. Displacements are measured using dial gauges. Figure (7) shows the test setup. Six strain gauges are installed on the tensile reinforcement of every tested specimen. The capacity of the loading actuator is $1000 \mathrm{KN}$, and the capacity of the load cell is $800 \mathrm{KN}$. Subsequently, vertical load is applied through the column stub by the load actuator. Load was applied by increments of $(25 \mathrm{KN})$ up to failure load. After every loading increment, loading was held to allow for crack monitoring and record of deflection values.

Table (1) Concrete dimensions, reinforcement steel ratio, and shear bolts array for the tested specimens.

\begin{tabular}{|c|c|c|c|c|c|c|c|c|c|}
\hline \multirow{2}{*}{$\begin{array}{l}\text { Slab } \\
\text { name }\end{array}$} & \multirow{2}{*}{$\begin{array}{l}\text { Slab } \\
\text { dimensions }\end{array}$} & \multirow{2}{*}{$\begin{array}{l}\text { Column } \\
\text { dimension }\end{array}$} & \multicolumn{2}{|c|}{$\begin{array}{l}\text { Tensile } \\
\text { reinforcement }\end{array}$} & \multicolumn{2}{|c|}{$\begin{array}{l}\text { Secondary } \\
\text { reinforcement }\end{array}$} & \multicolumn{2}{|c|}{ Shear bolts } & \multirow{2}{*}{$\begin{array}{l}\text { Shear } \\
\text { bolts } \\
\text { per } \\
\text { row }\end{array}$} \\
\hline & & & Layout & $\rho \%$ & Layout & $\rho^{`} \%$ & $\begin{array}{l}\mathbf{S}_{\mathbf{0}} \\
\mathbf{m m}\end{array}$ & $\begin{array}{l}\mathbf{S} \\
\mathbf{m m}\end{array}$ & \\
\hline NS1 & \multirow{6}{*}{ 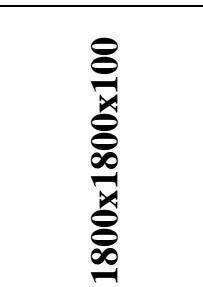 } & \multirow{6}{*}{ 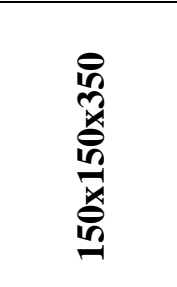 } & 12Ф10 & 0.58 & 10Ф10 & 0.48 & \multirow{3}{*}{\multicolumn{2}{|c|}{ N.A }} & \multirow{3}{*}{ N.A } \\
\hline NS2 & & & $16 \Phi 10$ & 0.78 & $10 \Phi 10$ & 0.48 & & & \\
\hline NS3 & & & 20Ф12 & 1.4 & 10Ф10 & 0.48 & & & \\
\hline SS1 & & & $12 \Phi 10$ & 0.58 & 10Ф10 & 0.48 & 45 & 50 & 4 \\
\hline SS2 & & & $20 \Phi 12$ & 0.78 & $10 \Phi 10$ & 0.48 & 45 & 50 & 4 \\
\hline SS3 & & & 20Ф12 & 1.4 & $10 \Phi 10$ & 0.48 & 45 & 50 & 6 \\
\hline
\end{tabular}




\section{EXPERIMENTAL RESULTS \\ 3.1 Crack patterns}

Crack patterns of the tested specimens after failure are shown in figure (9). For specimen (NS1), the first circumferential crack occurred at the column face, this crack was observed at $50 \mathrm{KN}$ load. With increase of the applied load, the radial cracks extended further towards the slab supports while circumferential cracks formed semi-closed rectangles around the column faces. At a load level of $191 \mathrm{KN}$, the column stub with a portion of the slab penetrated the slab. A trenched cone is formed due to the punching of the column through the slab. The trenched cone base extended to a distance of $80 \mathrm{~mm}$ from the column face at the bottom side of the slab. Nevertheless, splitting of the concrete cover has been observed outside the region of the trenched cone indicating false dimensions of the trenched cone for specimen (NS1), i.e. the dimensions of the trenched cone appeared larger because of splitting of the concrete cover outside the region of the trenched cone. Crack patterns of specimen (NS2) and (NS3) were similar to those of specimen (NS1). At a load level of $235 \mathrm{kN}$ for specimen (NS2) and load level $305 \mathrm{kN}$ for specimen (NS3), the column stud punched through the slab and a typical trenched cone is formed.

The trenched cone base extended to a distance of 100 and $200 \mathrm{~mm}$. respectively from the column face at the bottom slab side. The punching failures for these two specimens were in a brittle manner without enough warning.

For specimen (SS1), the first radial flexural crack initiated at about $50 \mathrm{kN}$ load at the column face. Then, cracks initiated at the region of the shear bolts and propagated with the load increase toward the slab supports. With the load increase, radial cracks were widened and extended further towards the slab supports. Failure occurred at a load level of $296 \mathrm{kN}$ after extensive yield of flexural reinforcement and enlarged flexural cracks, hence, flexural failure preceded punching of the column stub through the slab. For specimen (SS1), punching failure occurred outside the shear reinforced zone, the column stub together with the shear reinforced area around the column punched through the slab.

For specimen (SS2), the first flexural crack initiated at load level of $30 \mathrm{kN}$ in the shear strengthened zone. With the load increase, the radial flexural cracks extended toward the slab supports and some circumferential cracks appeared in the column vicinity. Subsequently, during the late stages of the loading procedure, flexural cracks were widened and extended further toward the slab supports, while other sub-flexural cracks initiated from the original cracks near the slab supports. Before failure occurrence, the slab was divided into several zones bounded by flexural radial and circumferential cracks. Finally, failure of specimen (SS2) occurred at load level of $304 \mathrm{kN}$ after extensive deformations and excessive cracks propagation. It has to be noted that presence of shear bolts diverted the failure mode from brittle to ductile mode of failure. Consequently, the column stub together with the shear strengthened zone punched through the slab forming a failure surface outside the shear-bolts zone. Punching occurred after the slab has reached its flexural capacity.

For specimen (SS3), the first flexural crack initiated at load level of $(90 \mathrm{kN})$ in the column vicinity. With the load increase, flexural cracks extended diagonally toward the slab supports passing through the slab quadrants. Consequently, some circumferential cracks initiated in the shear reinforced zone connecting the shear bolts. Subsequently, with the load increase, flexural cracks propagated in the column strips and extended toward the slab supports. Generally, specimen (SS3) exhibited little flexural cracks compared to slabs (SS1) and (SS2). Finally, failure occurred at a load level of $(390 \mathrm{kN})$ due to crushing of concrete diagonal struts in the column vicinity. Moreover, the column stub together with a small portion of the slab punched through the slab forming a trenched cone or pyramid. Furthermore, failure occurred in the shear strengthened zone. Hence, the failure surface initiated from the column face at the slab top side, passed through the first row of shear bolts, and ended at the second row of shear bolts.

\subsection{Load-maximum deflection relationships}

Table (2) includes the values of ultimate loads and deflections for the tested specimens. Generally, for all test specimens, the deflection increased in a linear manner up to point beyond first crack. Stiffness was decreased consequently with the propagation of flexural cracks, and then deflections increased in a non-linear manner up to failure load. 


\section{Analysis of Test Results}

\subsection{Punching Shear strength related to ratio of reinforcement}

Figure (10) shows the relation between the punching shear strength and the tensile reinforcement ratio for the first un-strengthened group. However, a significant increase in the ultimate punching load is observed with the increase of the tensile reinforcement ratio. Table (2) shows also similar relation for the strengthened slabs.

\subsection{Effect of shear bolts on punching Shear strength}

Using steel shear bolts for strengthening slab specimens enhanced their behavior in an excellent manner. Punching shear strength was increased compared to un-strengthened specimens significantly. Steel shear bolts play two significant roles. It acts as a transverse reinforcement intersecting the failure plan and carrying shear forces in the column vicinity. Also the vertical pre-stressing effect applied through tighten the bolts using a specific torque, initial axial force is generated in the section leading to an increase of punching capacity at the connection. Table (2) summarizes the punching strength values for strengthened specimens and compares the punching strength values for control specimens with those of strengthened specimens.

Figure (11) shows the effect of shear bolts on the punching shear strength of slab column connections for different reinforcement steel ratios. The percentage of increase in punching shear strength varied from $28 \%$ to about $55 \%$ depending on the ratio of flexural steel reinforcement.

\subsection{Ductility}

Un-strengthened specimen's punching failure modes showed a phenomenon of brittle failure. This behavior was enhanced through the study to a better more ductile failure when increasing tensile reinforcement ratio as well as with the strengthening technique used.

The following parameter is defined to measure ductility

$$
\Delta y
$$

Where $\mu_{\Delta}$ is the displacement ductility factor, $\Delta_{\mathrm{u}}$ is the maximum deflection at failure, and $\Delta_{\mathrm{y}}$ is the deflection corresponding to first yield of flexural reinforcement. However, the values of the displacement ductility factor for the tested specimens are presented in table (2).

Table (2) Results of shear strength, displacement, ductility factor for test specimens.

\begin{tabular}{|c|c|c|c|c|c|c|}
\hline & & & & & & \\
\hline Specimen & $\begin{array}{c}f_{c} \\
\left(N / m^{2} m^{2}\right)\end{array}$ & $\begin{array}{l}\rho \\
\%\end{array}$ & $\begin{array}{c}V_{u} \\
(k N)\end{array}$ & $\begin{array}{c}\Delta_{u} \\
(\boldsymbol{m m})\end{array}$ & $\begin{array}{c}\Delta_{y} \\
(\boldsymbol{m m})\end{array}$ & $\mu_{\Delta}$ \\
\hline CS-2 & 34.00 & 0.58 & 191.00 & 22.57 & 2.91 & 7.75 \\
\hline CS-3 & 28.66 & 0.78 & 235.00 & 24.92 & 3.90 & 4.23 \\
\hline CS-4 & 35.20 & 1.40 & 305.00 & 22.49 & 5.25 & 2.83 \\
\hline SS-2 & 34.01 & 0.58 & 296.00 & 35.58 & 2.10 & 16.94 \\
\hline SS-3 & 33.00 & 0.78 & 304.17 & 28.77 & 3.03 & 8.72 \\
\hline SS-4 & 38.28 & 1.40 & 390.00 & 28.41 & 7.73 & 3.68 \\
\hline
\end{tabular}

Results of displacement ductility factor indicated a significant ductility decrease with the increase in the reinforcement ratio.

Figure (12) shows the ratio of increase in the displacement ductility factor due to installation of shear bolts for different reinforcement ratios. The percentage of increase in displacement ductility factor varied from $30 \%$ to about $118 \%$ depending on the ratio of flexural steel reinforcement. 


\section{CONCLUSIONS}

1- The increase of tensile reinforcement ratio from $0.58 \%$ to $1.4 \%$ led to an increase in the punching shear capacity by almost $60 \%$.

2- The increase in the punching capacity for slab column connections due to strengthening by post installed shear bolts varied from $28 \%$ to almost $55 \%$. The value of strength increase depends on the reinforcement ratio of the slab and the number of post installed shear bolts.

3- Test results indicated an enhanced ductility for slabs strengthened by shear bolts. The displacement ductility factor is almost doubled for slabs with low reinforcement ratio. For slab with relatively high reinforcement ratio $(\rho=1.40 \%)$ the increase in the displacement ductility factor was about $25 \%$.

4- Post installed shear bolts changed the theme of punching shear failure by spreading and distributing the cracks, but most important is reducing the sudden brittle failure behavior.

\section{REFERENCES}

1. ACI Committee 318, "Building Code Requirements for Structural Concrete (ACI 318M14) and Commentary (ACI 318RM-14)," American Concrete Institute, Farmington Hills, MI, 2014.

2. Broms, "Concrete flat slabs and footings design method for punching and detailing for ductility", Doctoral thesis, Division of structural design and bridges, Royal institute of technology, SE-100 44, Stockholm, Sweden, 2005.

3. CSA Standard, A23.3-94, "Design of Concrete Structures", Canadian Standard Association, Ottawa, Canada, December 1994.

4. Egyptian Code of Practice, ECCS-203-2007, Egypt.

5. Euro-code 2, "Design of Concrete Structures, Part 1-1: General Rules and Rules for Buildings," CEN, EN 1992-1-1, Brussels, Belgium, 2004.

6. Kinnunen, S., "Punching of Concrete Slabs with Two-Way Reinforcement with Special Reference to Dowel Effect and Deviation of Reinforcement from Polar Symmetry", Transactions, No.198, Royal Institute of Technology, Stockholm, Sweden, (1963).

7. Moe, J., (1961) "Shearing Strength of Reinforced Concrete Slabs and Footings Under Concentrated Loads," Development Department Bulletin D47, Portland Cement Association, Skokie, Apr. 1961

8. Rizk, E., Marzouk, H., Hussein, A., and Hossin, M. (2011). "Effect of Reinforcement Ratio on Punching Capacity of RC Plates." Canadian Journal of Civil Engineering, 38(7), 729-740.

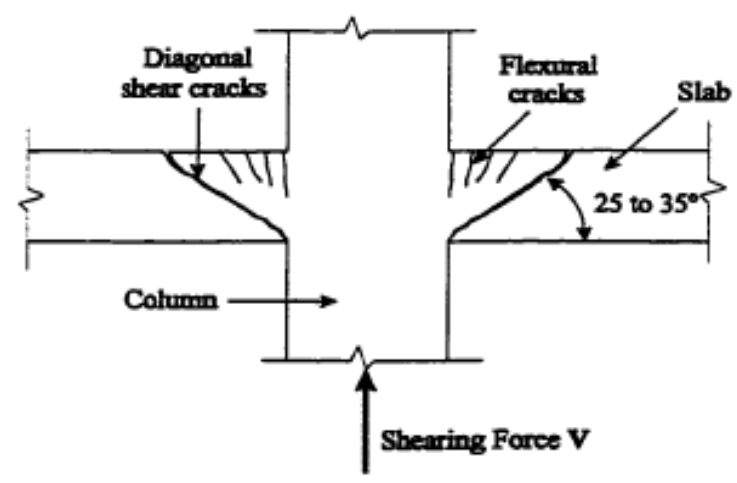

Figure (1) Slab flexural and shear cracks in the column vicinity 


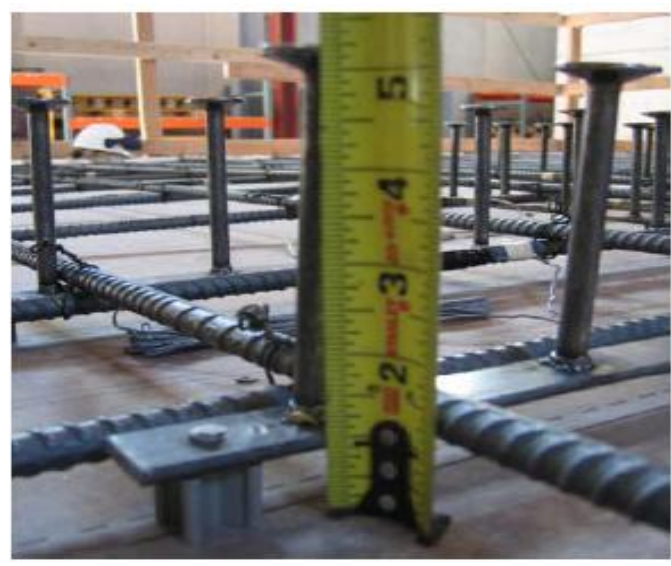

Figure (2) Headed shear studs in a slab column connection

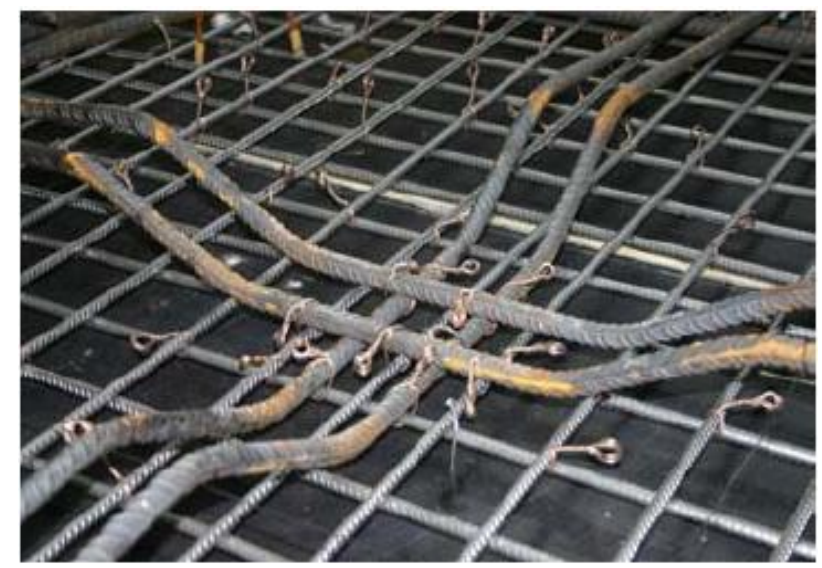

Figure (3) Bent up bars for ductility enhancement.

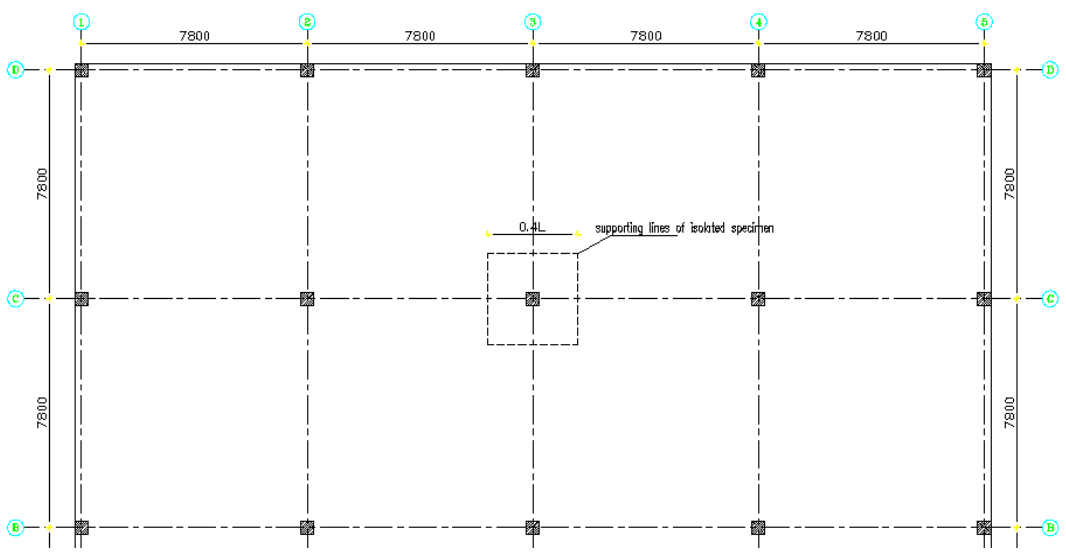

Figure (4) Plan view of prototype structure

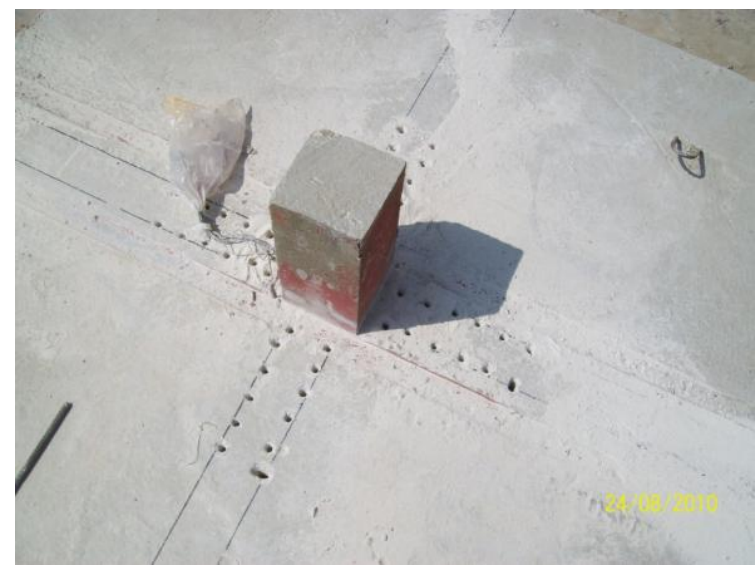

Figure (5) Slab specimen after holes drilling process

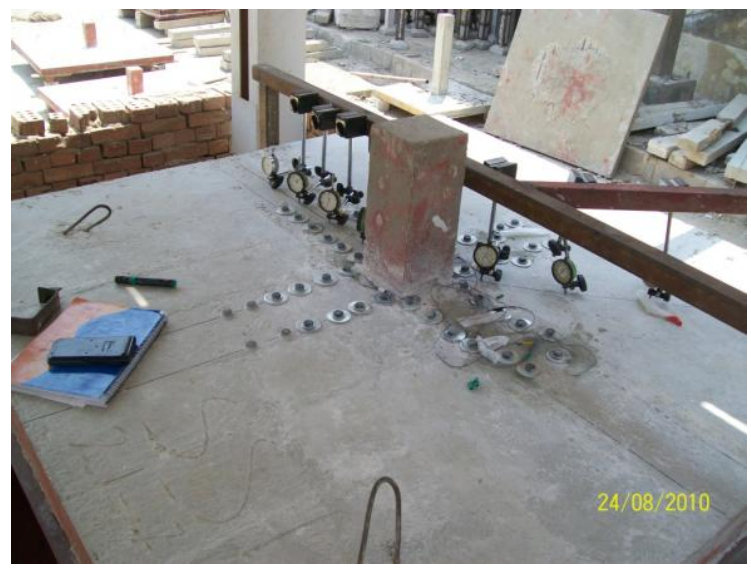

Figure (6) Slab specimen after the installation process of shear bolts 


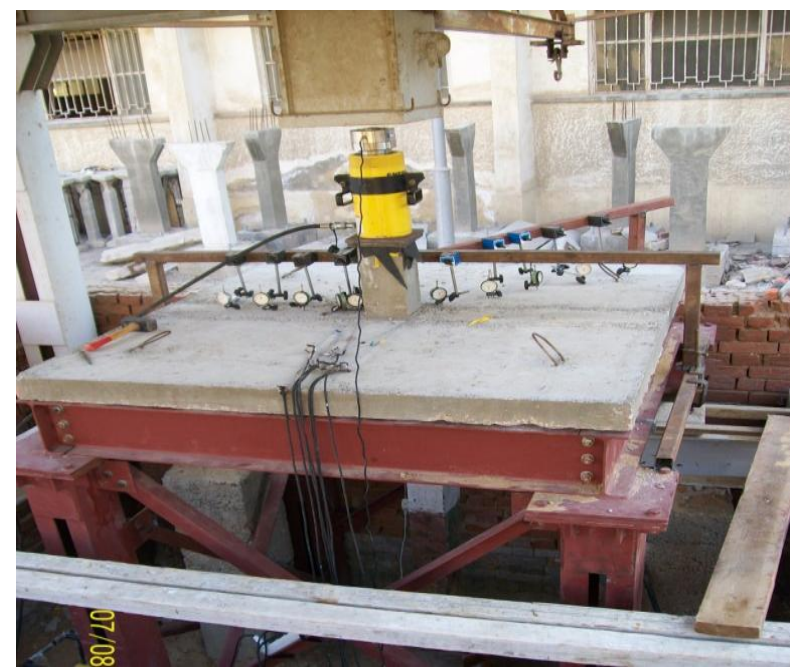

Figure (7) Test setup

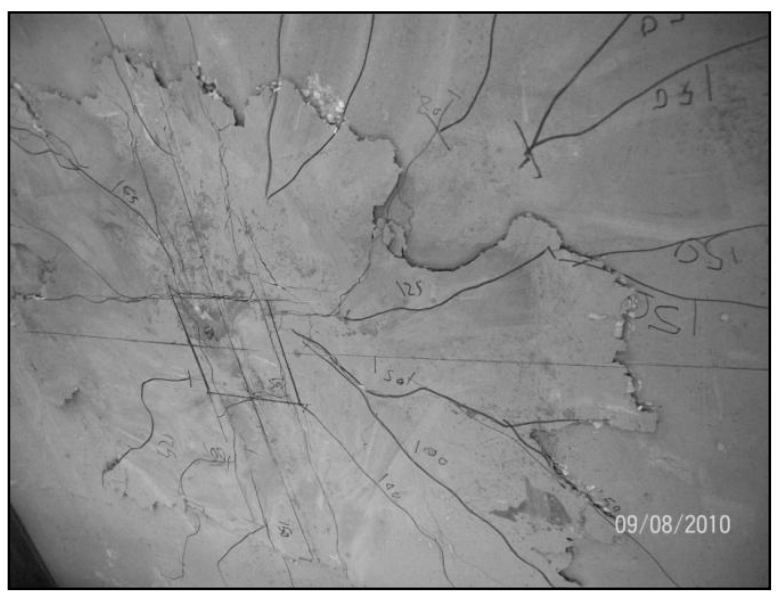

a) Specimen (NS1)

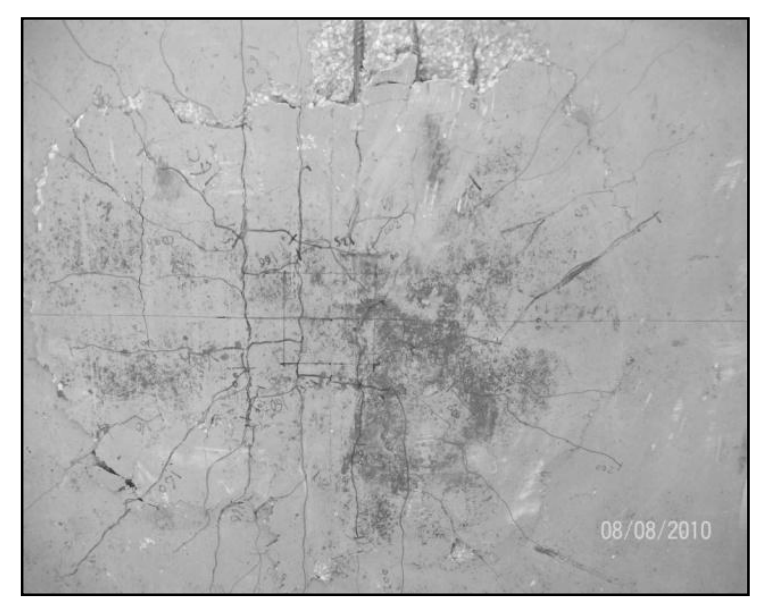

c) Specimen (NS3)

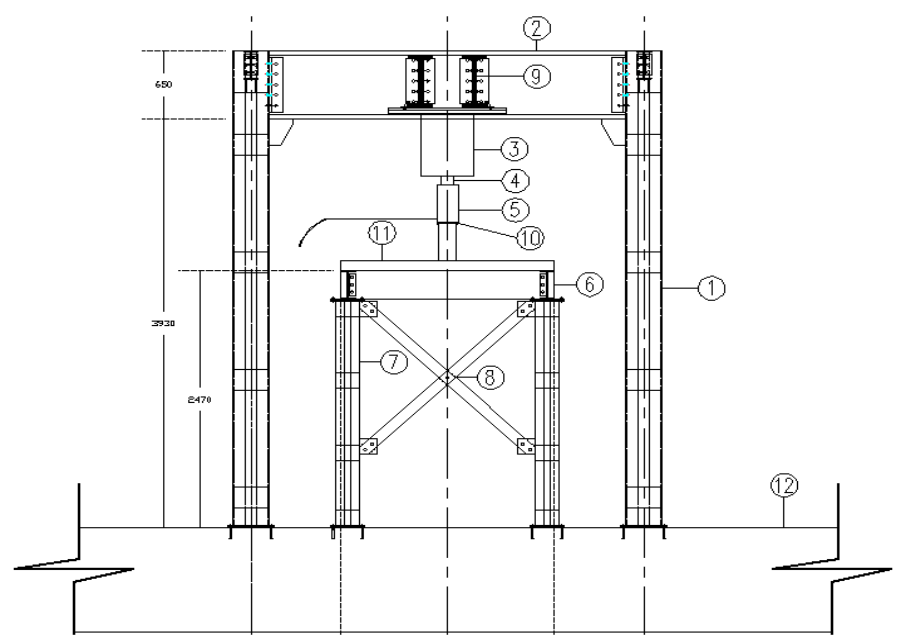

Figure (8) Elevation view of the testing frame

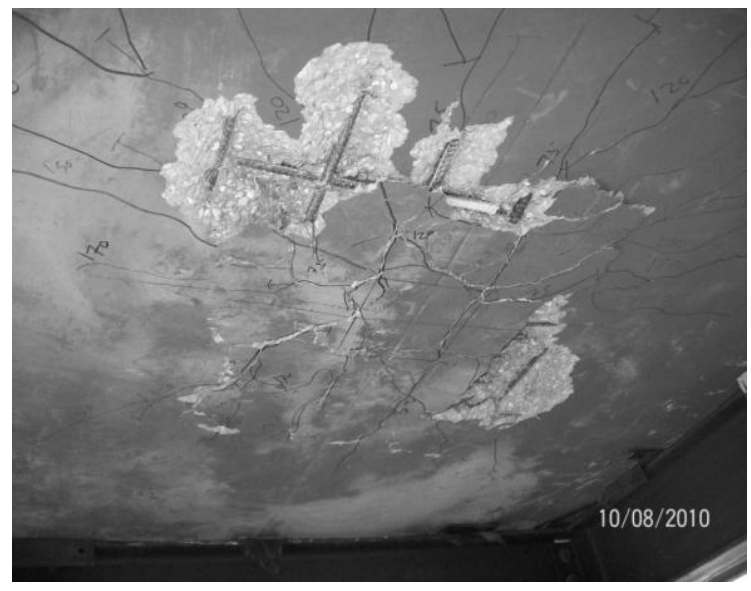

b) Specimen (NS2)

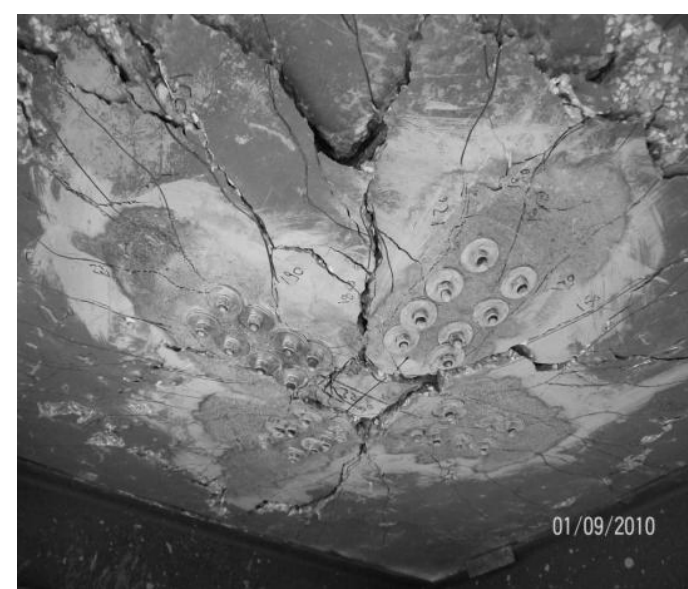

$\mathbf{k}$

d) specimen (SS1) 


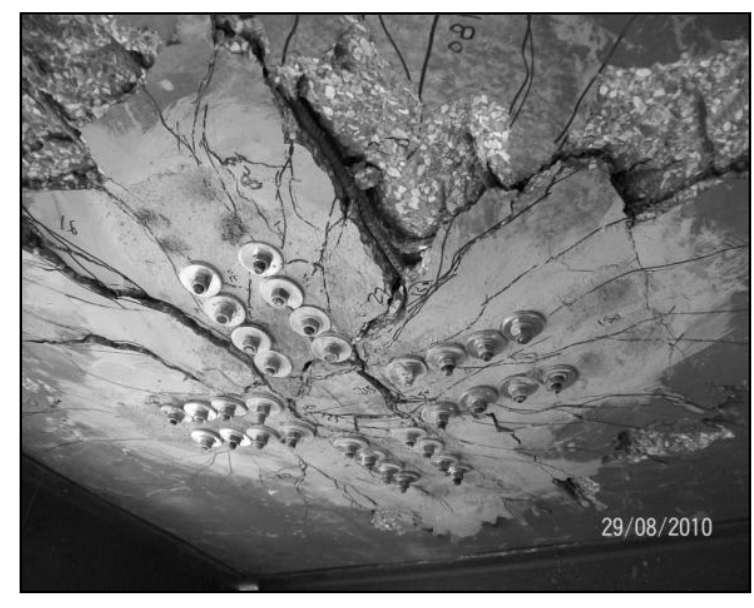

e) specimen (SS2)

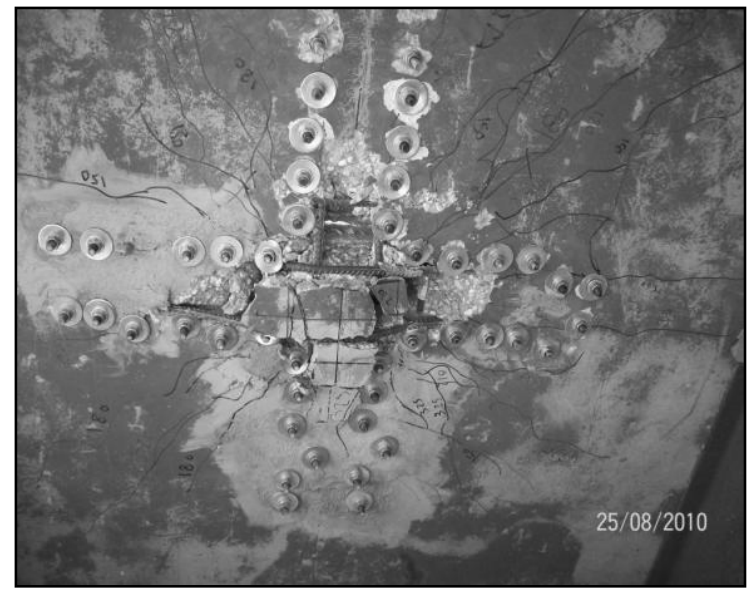

f) specimen (SS3)

Figure (9), crack patterns of the tested specimens

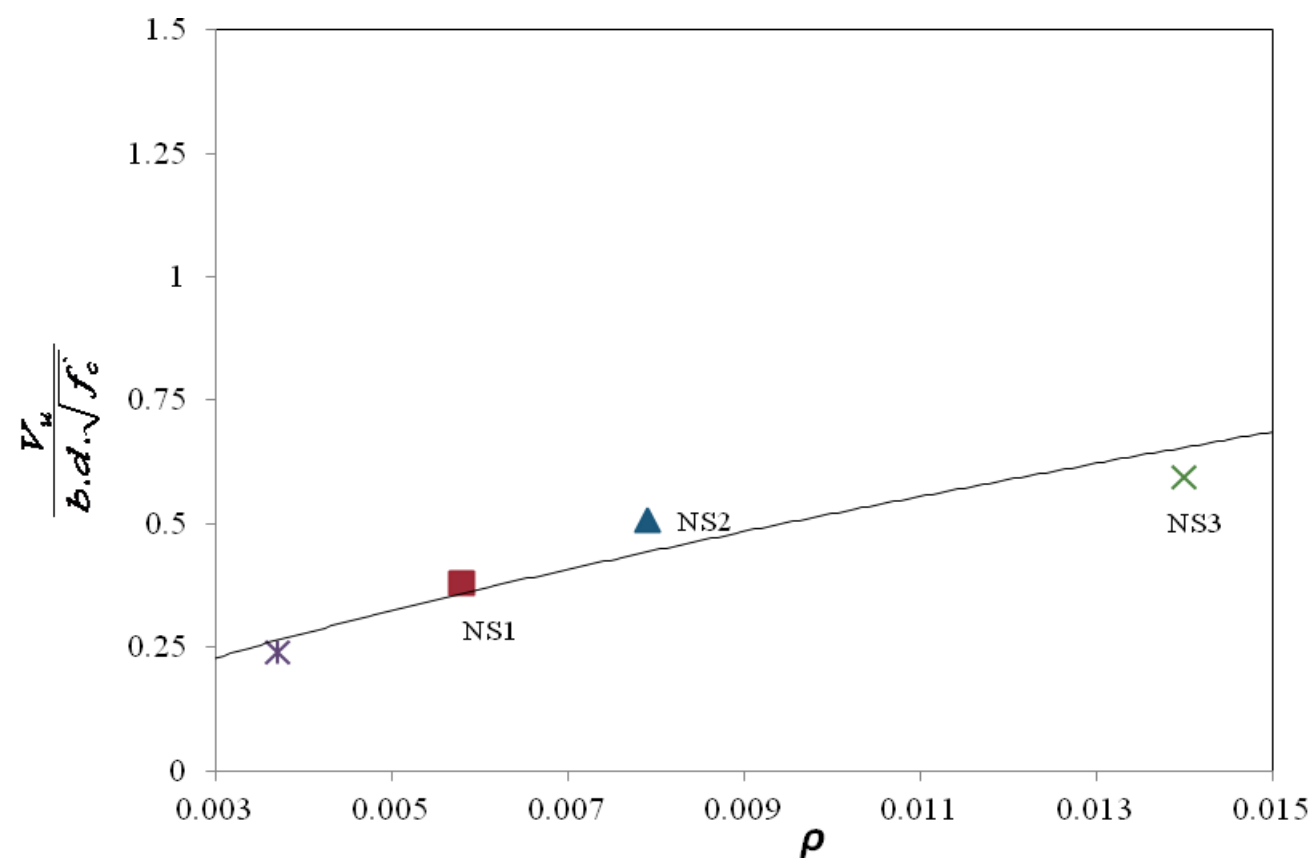

Figure (10), effect of reinforcement ratio on the punching shear strength of slabs 


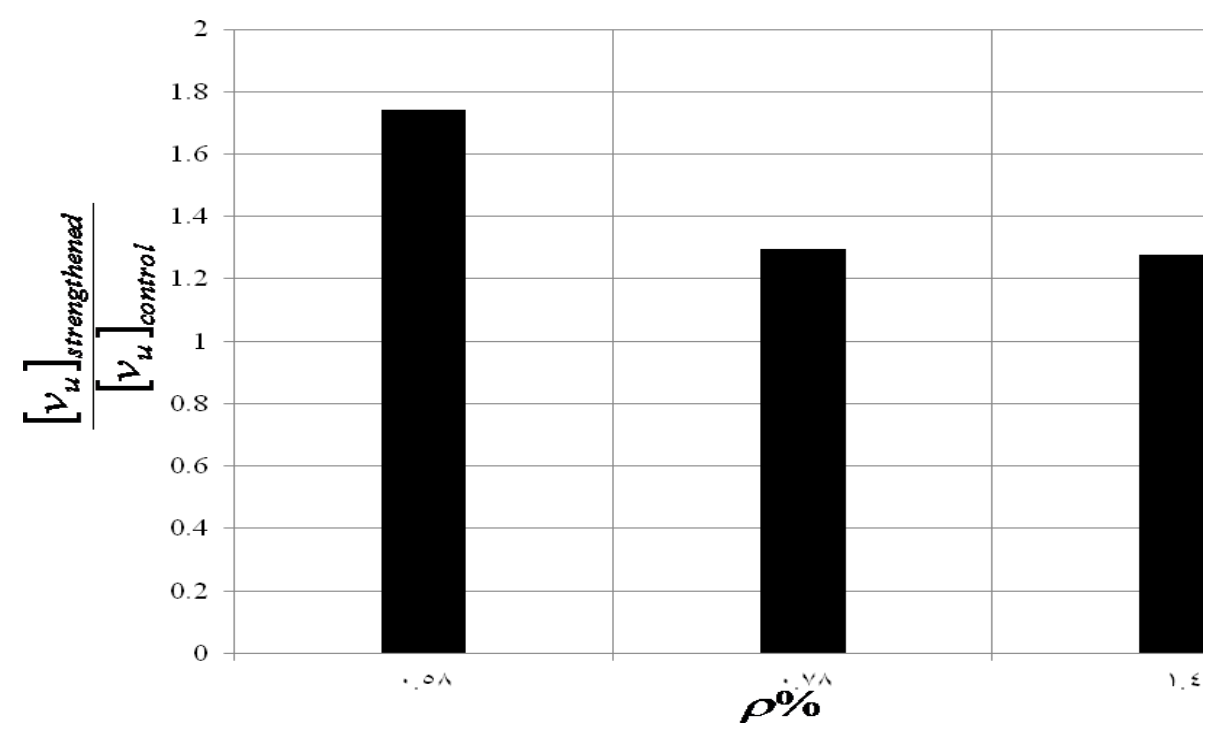

Figure (11), effect of shear bolts on punching shear strength for different ratios of flexural steel reinforcement

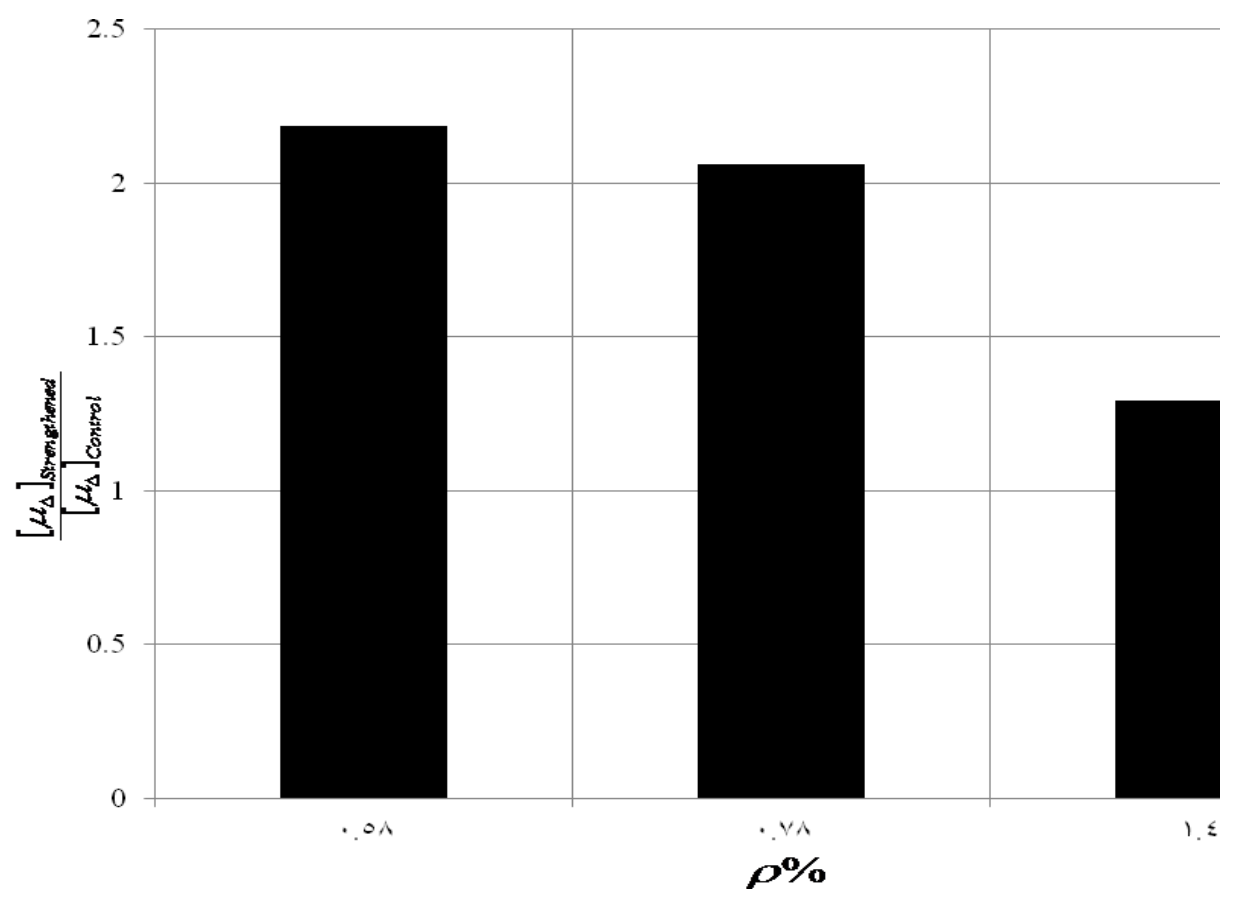

Figure (12), the ratio of increase in the displacement ductility factor due to installation of shear bolts 